\title{
Kurumsal Sosyal Sorumluluk Raporlaması ve Finansal Performans Arasındaki İliş̧ki: Borsa İstanbul'da İşlem Gören Kimya-Petrol-Plastik Sektörü Şirketleri Üzerine Bir Araştırma
}

\author{
Doç. Dr. A. Banu BAŞAR \\ Anadolu Üniversitesi, İ.I.B.F., Işsetme Bölümü, ESKIŞ̧EHIR
}

\begin{abstract}
$\ddot{O Z Z E T}$
Günümüzde sosyal sorumluluğa uygun olarak hareket eden işletmeler başarılarını uzun vadede ekonomiye çevreye ve topluma olan etkileri ile ölçmektedirler. Dolaylsıly işletmeler çevreye ve topluma karşı sorumlu bir şekilde faaliyetlerini yürütmeleri halinde uzun vadede kazançlı çıkacaklarını düşünmektedirler. Bu bakımdan günümüzde dünyada artan oranda sosyal sorumluluk faaliyetlerinin açıklandığı periyodik raporlar hazırlandığı görülmektedir. Bu çalışmada işletmelerin sosyal sorumluluğu ve finansal performans iliş̧kisinin incelenmesi amaçlanmaktadır.

Bu nedenle çalışmada 2010-2012 yılları arasında BIST Kimya, Petrol, Plastik Endeksinde yer alan işletmelerin GRI (Global Reporting Initiative - Küresel Raporlama Girişimi) tarafindan belirlenmiş sosyal sorumluluk kriterlerine göre raporlama düzeyi araştırllacak ve ardindan elde edilen sonuçların finansal performans ölçütleri ile olan ilişkisi analiz edilecektir.
\end{abstract}

Anahtar Kelimeler: Kurumsal Sosyal Sorumluluk, Finansal Performans, Raporlama

JEL Sinıflamast: M14, M41

The Relationship Between Corporate Social Responsibility and Financial Performance: A Study on BIST Chemical, Petroleum and Plastic Index

\section{ABSTRACT}

In today's World the companies which act according to social responsibility, evaluate their sucess according to economic, environmental and social effects in the long run. For this reason if they operate in the social responsible manner, they think that they will be sucessful. So the information which define the social responsibility activities of companies apart from the financial information tend to increase in the business World. In this study it is aimed to analyse corporate social responsibility and financial performance relationship.

Thereby the companies which are BIST Chemical - Petroleum and Plastic sector will be studied between the years 2010-2012 according to the criteria which are determined by GRI (Global Reporting Initiative). In this anaysis firstly the reporting level of the companies according to criteria and then the relationship between the the results and financial performance will be examied.

Key Words: Corporate Social Responsibility, Financial Performance, , Reporting

JEL Classification: M14, M41

\section{GíRIŞ}

Kurumsal sosyal sorumluluk, bir işletmenin hem iç hem de diş çevresindeki tüm paydaşlarına karşı etik ve sorumlu davranması, bu yönde kararlar alması ve uygulaması seklinde tanımlanabilir. Özellikle 1980 li yılların 
A. B. Başar / Kurumsal Sosyal Sorumluluk Raporlaması ve Finansal Performans Arasındaki İlişki: Borsa İstanbul'da Iş̧lem Gören Kimya-Petrol-Plastik Sektörü Şirketleri Üzerine Bir Araştırma

başından itibaren işletmelerin sadece ekonomik faaliyetleriyle değil, aynı zamanda sosyal sorumluluk faaliyetleriyle de değerlendirilmeleri gereği vurgulanmaktadır. Günümüzde sosyal sorumluluğa uygun olarak hareket eden işletmeler başarılarını uzun vadede ekonomiye çevreye ve topluma olan etkileri ile ölçmektedirler. Dolayısıyla işletmeler çevreye ve topluma karşı sorumlu bir şekilde faaliyetlerini yürütmeleri halinde uzun vadede kazançlı çıkacaklarını düşünmektedirler. Ancak kurumsal sosyal sorumluluk kavramının günümüzde geldiği konum, işletmelerin sadece paydaşlarına karşı sorumluluk üstlenmesiyle sınırlı kalmamakta bunun da ötesinde üstlendiği sorumlulukları işletme içindeki tüm süreçlere yaymak, bu şekilde yarattığı etkileri ölçmek denetlemek ve raporlamak boyutlarını da içermektedir. (Aktan, Börü, 2007).

Günümüzde birçok şirket kendi sosyal sorumluluk faaliyetlerini açıkladıkları periyodik raporlar hazırlamaktadırlar. Finansal raporlamanın doğal bir uzantısı olarak sosyal sorumluluk raporları işletmenin çevresel, ekonomik ve sosyal performansını açıklamada işletme raporlamasının kapsamını genişletmektedir. Sosyal sorumluluk raporlaması geleneksel finansal raporlamanın kapsamını toplumsal fayda yönünde genişletmekte ve aynı zamanda menfaat sahiplerine finansal konularda hesap verme şeklinde ifade edilebilecek geleneksel rolün ötesinde işletme sorumluluklarının genişletilmesi anlamını taşımaktadır. Son zamanlarda sosyal sorumluluk performansı ile ilgili bilgiler işletmelerin yıllık faaliyet raporlarında yer almaya başlamıştır. Birçok işletme sosyal sorumluluk raporları ile finansal raporlarını tek bir faaliyet raporunda birleştirmektedir. (Başar, Başar 2006)

İşletmelerde sosyal sorumluluk bilincinin artmasıyla birlikte bu faaliyetlerin işletmenin finansal performansına olan etkisi de gündeme gelmiştir. Dünyada bu kapsamda yapılmış bir çok araştırma bulunmaktadır. Ülkemizde ise yapılan çalışma sayısı ise çok sınırlıdır. Bu çalışmanın amacı da Türkiye'de faaliyet gösteren işletmelerin sosyal sorumluluk raporlamaları ile finansal performans arasındaki ilişkiyi ortaya koymaktır.

\section{SOSYAL SORUMLULUK RAPORLAMASI VE FINANSAL PERFORMANS İLİSTKISI}

İşletmelerin sosyal sorumluluğu çok uzun yıllardan beri var olmasına karş1lık esasında sosyal sorumluluğun analizi, kuramsal çerçevesi, ölçümü, amprik yöntemleri henüz tam anlamıyla açıklığa kavuşmadığ 1 için çok yeni olarak kabul edilmektedir. Dolayısıyla sosyal sorumluluk raporları da işletmeler arasında farklılık göstermektedir. Aynı zamanda paydaşlar da işletmelerin sosyal ve çevresel faktörlerle uyum içinde faaliyetlerini yürütmelerini talep etmektedir. (Oeyono, Samy, Bampton, 2011) , Kurumsal sosyal sorumluluk ile ilgili çalışmalar incelendiğinde bu faaliyetlerin raporlanması ve yönetilmesi ile ilgili standartların geliştirilmesinde problemler yaşanabildiği görülmektedir. Dolayısıyla yaklaşık olarak hangi faaliyetlerin kurumsal sosyal sorumluluğu oluşturduğu üzerinde uzlaşmaya varılmış bir tanım ve bu faaliyetlerin ve işletme performansının ölçülmesine yönelik bir temel bulunmadığı vurgulanmaktadır. (Aras ve diğerleri 2010) 


\section{A. Sosyal Performans ve Finansal Performans Etkileșimi İle İlgili Hipotezler}

İşletmelerin finansal ve sosyal performans ilişkisi göz önünde bulundurulduğunda iki farklı konu ortaya çıkmaktadır. Bunlardan birincisi ilişkinin yönüdür yani, sosyal ve finansal performansın pozitif ya da negatif olarak ilişkili olup olmadığı veya hiç ilişkili olmadığı ile ilgilidir. Diğer konu ise nedensel ilişki ile ilgilidir. Yani sosyal performansın finansal performansı $\mathrm{m} 1$ yoksa finansal performansın sosyal performansı mı etkilediği ile ilgilidir. Bu iki konu altı adet olası nedensel ve yönsel hipotezi ortaya koymaktadır. (Preston, O'Bannon, 1997) Buna göre Tablo 1'de sosyal performans1 ve finansal performansin birbirlerini etkileme ya da sinerjik etkiye sahip olma durumu açıklanmaktadır.

Tablo 1: Sosyal Performans ve Finansal Performans Etkileşimi

\begin{tabular}{|lc|l|l|}
\hline \multicolumn{1}{|c|}{ ETKI I Performans Finansal } & Sosyal Etki Hipotezi & \multicolumn{1}{c|}{ NEGATÍF } \\
\hline $\begin{array}{l}\text { Sosyal } \\
\text { Performansı Etkiler }\end{array}$ & Dengeleme Hipotezi \\
\hline $\begin{array}{l}\text { Finansal Performans } \\
\text { Performans1 Etkiler }\end{array}$ & Uygun Fonlar Hipotezi & $\begin{array}{l}\text { Yönetsel Firsatçılık } \\
\text { Hipotezi }\end{array}$ \\
\hline $\begin{array}{l}\text { Sosyal Performans ve Finansal } \\
\text { Performans Eş Etkinliktedir }\end{array}$ & Pozitif Sinerji Hipotezi & Negatif Sinerji Hipotezi \\
\hline
\end{tabular}

Sosyal Etki Hipotezi: Bu hipoteze göre çeşitli işletme paydaşlarının ihtiyaçlarının karşılanması işletmeyi arzulanan finansal performansa ulaştıracaktır. Ortaklar dışındaki çeşitli tarafların beklentilerini karşılayamama, işletmenin risk priminin artması ve yüksek maliyete ve/veya karda kayıplara yol açacaktır. Dolayısıyla paydaşların taleplerini karşılama işletmenin finansal performansına olumlu etkide bulunmasını sağlayacaktır. Tam tersine bu grupların taleplerini karşılamama da negatif finansal etki edecektir.

Dengeleme Hipotezi: Buna göre sosyal performans bağımlı değişkendir ve sosyal başarı finansal maliyetleri de içerir. Buna göre sosyal sorumluluk faaliyetleri (çevre koruma, bağış, ..) işletmeden sermaye ve diğer kaynakların çekilmesine neden olur. $\mathrm{Bu}$ durum da daha az sosyal sorumluluk uygulamasına sahip işletmelere göre dezavantajlı bir durum yaratacaktır. Sonuçta rakiplerle karşılaştırıldığında yüksek seviyede sosyal performans işletmenin finansal performansını düşürecektir.

Uygun Fonlar Hipotezi: Bu hipoteze göre sosyal ve finansal performans gerçekten de pozitif olarak ilişkilidir. Fakat finansal performanstan sosyal performansa doğru geçici ilişki bulunmaktadır. İşletmeler iyi bir kurumsal vatantaş olabilmeye ilişkin kuralları uygulamak isteseler bile mevcut faaliyetleri elindeki kaynaklara bağlı olarak değişebilir. $\mathrm{Bu}$ durumda belirli bir zaman diliminde işletme karlılığı işletmenin sosyal performans projelerini artıracaktır. 
A. B. Başar / Kurumsal Sosyal Sorumluluk Raporlaması ve Finansal Performans Arasındaki İlişki: Borsa İstanbul'da İslem Gören Kimya-Petrol-Plastik Sektörü Şirketleri Üzerine Bir Araştırma

Yönetsel Fursatçılık Hipotezi: İşletme yöneticilerinin paydaşların ve ortakların aleyhine olabilecek şekilde kendi özel amaçlarının peşinde koşabildikleri görülmektedir. Dolayısıyla yönetimin işletme ile ilgili olarak alacakları kararlarda kendi özel amaçlarına öncelik vermeleri söz konusu olabilir. Finansal performansın güçlü olduğu zamanlarda yönetim kendi özel kısa vadeli amaçlarını arttırmak için sosyal harcamaları azaltarak kazanç sağlama yoluna gitmektedirler. Buna karşın finansal performansın zayıf olduğu zamanlarda ise yönetim bu durumu telafi etmek için dikkat çekilen sosyal programlara girişmektedir.

Pozitif ya da Negatif Sinerjiler Hipotezi: Buna göre sosyal ve finansal performans sinerjiktir ya da en azından ya da kendi aralarındaki etkileşim zamana bağlı olarak istatistiksel verilerden belirlenemez.

Yukarıdaki açıklamalardan da anlaşılabileceği gibi sosyal sorumluluk faaliyetlerinin işletmenin finansal performansı üzerine etkisi farklı şekillerde ortaya çıkabilmektedir. Dolayısıyla söz konusu ilişki pozitiften negatife doğru geniş bir spektruma dayanabilmektedir.

\section{B. Paydaşlar Açısından Kurumsal Sosyal Sorumluluk ve İşletme Performansı İlişsisi}

Kurumsal sosyal sorumluluk faaliyetlerinin işletme karlılığını arttırma mekanizması esasında sosyal sorumluluk faaliyetlerinin çeşitli paydaşlar üzerindeki etkisini inceleme yoluyla anlaşılabilir. Bu durumda kurumsal sosyal sorumluluk faaliyetleri ve karlılık arasındaki ilişkinin incelenmesine yönelik beş adet paydaş grubu incelenmektedir. (Lech, 2013)

Çalışanlar: İşçi sendikalarına yönelik politika ve uygulamalar, karar almada çalışanların katılımı, ücret politikası ve çalışma koşulları bir işletmenin çalışanlarına karşı sosyal sorumluluk uygulamaları hakkında bir imaj oluşturur. $\mathrm{Bu}$ bakımdan yüksek standartların uygulanmasıyla işletmeler çalışanlarının gereksinimlerine cevap verebilir, iş performaslarının artmasını sağlayabilir ve işletmenin finansal performansını arttırabilir. Tatmin edilmiş olan çalışanlar daha yüksek motivasyona sahip oldukları ve daha yüksek verimlilik gösterdikleri açıktır. Güçlü sosyal sorumluluk uygulamalarına sahip işletmeler genellikle daha nitelikli iş başvurularını çekmektedir ve çalışanlarını elinde tutabilmektedir. $\mathrm{Bu}$ da çalışan devir hızının düşmesine ve işe alma ve eğitim maliyetlerinin düşmesine neden olmaktadır. Sosyal sorumluluk uygulamalarına bağlı olarak insan sermayesi birikimi de daha iyi hale gelmiş finansal performansın ve rekabet avantajı yaratmanın kaynağı olarak kabul edilmektedir.

Tüketiciler: İşletmelerin üretmiş oldukları ürünlerin kullanımı ile ilgili olarak tüketici sağlı ve güvenliği, etik reklam standartları gibi konularda dikkatli olmaları gerekmektedir. Bu bakımdan işletmenin tüketicilere karşı sorumlu olduğu gibi konularda işletme şeffaf politikaları olumlu işaretler verir. Bu olumlu işaretler marka imajını, işletme itibarını ve müşteri sadakatını arttırır. Marka imajı ve işletme itibarı ise işletmeye rekabet avantajı sağlayan değerli bir maddi olmayan duran varlıktır. Ürünün kalitesi ve güvenliği ile ilgili Pozitif tüketici algısı satışların artmasını ve işletme performansının artmasını sağlar. Ürün 
kalitesi ve güvenliği ile ilgili olumlu tüketici algısı satışların artmasına ve performansın yükselmesine neden olmaktadır.

Yatırımcılar: Yatırımcılar yönünden kurumsal sosyal sorumluluk uygulamaları karar almada ortakların katılımı, ortakların haklarına sayg, denetçinin bağımsızlı̆̆ 1 , içeriden öğrenenlerin ticaretine yönelik politikalar finansal ve finansal olmayan açıklamalarda şeffaflık, kilit yöneticilere yönelik şeffaf ücretlendirme politikalarını inceler. Daha iyi kurumsal yönetim standartlarının uygulanması işletme performansını arttrmaktadır. Yatırımcılara yönelik kurumsal sosyal sorumluluk ilkelerini benimseyen işletmelerin daha şeffaf oldukları ve daha az rüşvet ve yolsuzluk riskine maruz kaldıkları vurgulanmaktadir.

Toplum: Toplum açısından kurumsal sosyal sorumluluk uygulamaları genellikle bağışlar, kamu-özel sektör işbirlikleri, toplumla ilişkiler ve sosyal ve ekonomik gelişim sorunlarına katılma olarak ele alınmaktadır. Bu faaliyetler genellikle marka imajı ve itibar oluşturma araçları olarak görülmektedir. $\mathrm{Bu}$ bakımdan kurumsal hayırseverlik faaliyetlerinin hayırseverlik anlamında yapılacak katkıların stratejik olarak işletmenin imajını ve itibarını yükselttiğinden işletmenin finansal performansı üzerinde olumlu etkisi bulunmaktadır. Kurumsal hayırseverlik işletmenin ana paydaşlarıyla daha iyi ilişkiler kurmasını sağlayan bir araçtır.

Ayrıca toplumun kalkınmasına yönelik olarak yapılan yatırımlar işletmeye vergi tasarrufu ve azaltılmış yasal yükler aracılığıyla rekabet avantajı elde etmelerini sağlayacaktır.

Ayrıca yerel çevreyle ilgili olarak çevrenin korunması faaliyetleri de kurumsal sosyal sorumluluk anlamında temel faktör olarak ortaya çıkmaktadır. Çevreyle uyumlu ürün, süreç ve yönetim sistemleri de maliyet tasarrufları ya da elde edilen gelirler aracılığıyla karlılığı arttırır. Tüketicilerin çevreyle uyumlu ürünleri tercih etmeleriyle işletmenin gelirleri artacaktır. Diğer taraftan çevresel yönetim sistemlerine yapılan yatırımlar da çevresel krizler, hammadde atıkları, verimsiz üretim süreçleri nedeniyle oluşan maliyetleri düşürecektir.

Tedarikçiler: Tedarikçilere yönelik sosyal sorumluluk uygulamaları tedarikçi ürünlerinin sağlık ve güvenlik konularını, tedarikçilerin çevresel etkilerini, ham maddelerin etik yollardan temin edilmesi tedarikçilerin işyerinde çocuk işçi çalıştırma ya da insan hakları ihlalini önlemeye yönelik uygulamaları içermektedir. Tedarikçilerin yüksek oranda kurumsal sosyal sorumluluk standartlarına bağlı kalması bir işletmenin global pazarda imajını kuvvetlendirecek ve finansal performansını arttıracaktır. Diğer taraftan tedarikçilerin kurumsal sosyal sorumluluk standartlarının ihlali de işletmenin imajına zarar verecektir ve performansını olumsuz yönde etkileyecektir.

\section{LITERATÜR TARAMASI}

Sosyal sorumluluk raporlaması ve finansal performans arasındaki ilişkiyi açıklamak için esasında bir çok çalışma yapılmıştır. Bu çalışmalardan çıkan bir görüş işletmelerin sosyal sorumluluk ve finansal performans arasında bir mübadele ile karşılaştıkları yönündedir. $\mathrm{Bu}$ görüşe göre sosyal sorumluluk 
A. B. Başar / Kurumsal Sosyal Sorumluluk Raporlaması ve Finansal Performans Arasındaki İlişki: Borsa İstanbul'da Iş̧lem Gören Kimya-Petrol-Plastik Sektörü Şirketleri Üzerine Bir Araştırma

faaliyetlerinden dolayı işletmeler maliyetlere katlanmaktadırlar bu da diğerlerine göre ekonomik açıdan dezavantajlı konuma getirmektedir. Bu nedenle de finansal performans ile sosyal sorumluluk faaliyetleri arasında ters ilişki bulunduğu bulunmaktadir. (Andersen, Olsen, 2011; Ullmann ,1985; Auperle, Caroll, Hatfield, 1985) Buna karşın diğer görüş ise işletmelerin sosyal sorumluluk faaliyetlerine yönelik belirli maliyetlerin minimal seviyede olduğu ve bundan dolayı sosyal sorumluluk faaliyetleri nedeniyle çalışan morali ve verimlilik açısından işletmelerin yarar sağladığı yönündedir. Dolayısıyla sosyal performans açısından etkin olan yöneticilerin daha fazla yönetim becerisine sahip olmalarından dolayı ve daha fazla kar yarattıkları ileri sürmektedir. Bu durumda daha fazla sosyal sorumluluk faaliyetleri potansiyel ekonomik faaliyetlerle sonuçlanacak şekilde işletmenin itibarını ve paydaşlarla (bankalar, yatırımcılar, devlet kuruluşları gibi) olan ilişkilerini artıracaktır. İş dünyası ile ilgili klasik literatür kurumsal sosyal sorumluluğun kısa vadeli maliyetleri ortaya çıkarmasına rağmen bunun karşılığının işletmeye uzun vadede döneceğini ortaya koymaktadır. Buna göre işletmelerin daha az yasal düzenleme ile daha fazla sosyal meşruiyet elde ettiği ve bunun da uzun vadeli karlılı̆̆ açısından olumlu olduğu vurgulanmaktadır. Bu kapsamda yer alan üçüncü görüş ise sosyal sorumluluk faaliyetlerinin maliyetinin önemli olduğu ancak bunun da diğer işletme maliyetleri ile dengelendiği yönündedir. (Arsoy, Arabacı, Çiftçioğlu, 2012)

Esasında şaşırılacak kadar fazla sayıdaki çalışmada sosyal sorumluluk faaliyetleri ile finansal performans arasında negatif ilişki bulunduğu görülse de Roman ve diğerlerinin (1999) yeniden düzenlemiş olduğu çalışma başka bir sonucu ortaya çıkarmaktadır. Bu kapsamda yapılmış olan yeni sınıflandırma negatif korelasyon gösteren çalışmaların sayısında önemli bir azalma yaratmıştır. $\mathrm{Bu}$ durumda incelenen çalışmaların büyük çoğunluğunun pozitif ilişki gösterdiği saptanmıştır. Diğer taraftan Orlitzky ve diğerleri 2003 yılında 52 adet çalışmayı incelemiştir. Buna göre sosyal sorumluluk ve finansal performans arasında pozitif ilişki olduğunu saptamışlardır. Allouche ve Laroche (2005) sosyal sorumluluk ve finansal performans ilişkisini incelemiştir. Çalışmanın sonuçlarına göre sosyal performansın finansal performans üzerinde pozitif etkide bulunduğu saptanmıştır. Wu da 2006 yılında sosyal sorumluluk finansal performans ilişkisini araştırmıştır. İşletme büyüklüğünün sosyal performanstaki rolünü incelemiştir. Sosyal performans ve finansal performans arasında pozitif ilişki bulunduğunu saptamıştır. $\mathrm{Bu}$ da sosyal sorumluluk faaliyetleri nedeniyle ortaya çıkan maliyetlerin düşük olabileceği ve bu nedenle sosyal sorumluluğa ilişkin faaliyetler nedeniyle işletmenin fayda elde edebileceği yönündedir. Buna göre işletme büyüklüğünün sosyal sorumluluk faaliyetleri ve finansal performans üzerinde görülür bir etkisi yoktur. (Beurden, Gössling, 2008)

$\mathrm{Bu}$ bakımdan University of Iowa'da literatür taramasına yönelik olarak yapılan araştırmada sosyal sorumluluk raporlaması ve finansal performans ilişkisini inceleyen 52 çalışmada ağırlıklı olarak daha sosyal sorumluluk bilincine sahip işletmelerin daha sağlam finansal sonuçlara sahip olduğu belirlenmiştir. Ancak 2004'de ACCA tarafından yürütülen bir anket ise karlılık ve sosyal 
sorumluluk raporlaması arasında marka geliştirme ve daha iyi çalışan morali gibi maddi olmayan faydalar sağlamasına rağmen sağlam bir ilişki bulunmadığı ortaya çıkmıştır. Aupperle ve diğerleri (1985) bu alandaki araştırmacıların işletmelerin sosyal sorumluluk faaliyetlerini kendi ölçümlerine dayalı olarak ölçme eğiliminde olduklarından dolayı sosyal sorumluluğun belirlenmesinin finansal performansın belirlenmesi kadar açık olmadığını vurgulamıştır. Dolayısıyla bu durum bir işletmenin diğer işletmeye göre sosyal sorumluluk faaliyetlerini karşılaştırmayı zorlaştırdığını ifade etmiştir. KSS ve kârlılık arasındaki ilişkiyi bir yıldan beş yıla kadar olan süreyle araştırmışlar ve yönetimin eğilimi ve sosyal sorumluluk arasında herhangi bir ilişkiye rastlamamışlar ve ekonomik ve etik bileşenler arasında ters ilişki bulunduğunu saptamışlardır. (Peters ve Mullen, 2009). Diğer taraftan D'Arcimoles ve Trebucq 2002 de Fransız firmaları üzerinde araştırma yapmışlar ve kurumsal sosyal sorumluluk ve finansal performans arasında nötr ilişki saptamışlardır. Ancak, Cochran ve Wood kurumsal sosyal sorumluluk ve finansal performans arasında zayıf pozitif ilişki saptamışlardır. Vershoor 1995 de ABD'de 500 büyük işletmede araştırma yapmış ve satışlar ya da karlılık açısından sosyal sorumluluk faaliyetleri ile güçlü pozitif ilişki saptamışlardır.

Balabanis ve diğerleri 1998 de İngiltere'de 56 büyük işletmeyi incelemiş ve sosyal sorumluluk ve ekonomik performans (özkaynak karlılı̆̆ sermaye piyasası performansı) arasında zayıf ilişki bulunduğunu saptamıştır. Ruf ve diğerleri işletmenin sosyal performansındaki değişim ve kısa vadeli çıkarları (örneğin satışlardaki büyüme) ve uzun vadeli çıkarları (örneğin satış karı) arasında pozitif ilişki bulunduğunu saptamışlardr. Moneva ve diğerleri de sosyal sorumluluk ve finansal performans arasında pozitif ilişki bulunduğunu saptamışlardır.

Türkiye'de ise Arsoy ve diğerleri kurumsal sosyal sorumluluk ve finansal performans ilişkisini Kurumsal yönetim endeksine tabi 28 adet işletme üzerinde araştırmış ve sonuçta kurumsal sosyal sorumluluğun daha iyi performansa yol açtığını saptamışlardır. Aynı şekilde Aras ve diğerleri de Borsa İstanbul'a kote işletmelerde sosyal sorumluluk politikaları ve finansal göstergeler arasındaki ilişkiyi analiz etmişler ve işletme büyüklüğü ve sosyal sorumluluk arasında ilişki bulunduğunu saptamışlardır. Ancak işletmenin sosyal sorumluluğu ve finansal performans arasında anlamlı bir ilişki saptayamamışlardır.

\section{ARAŞTIRMA}

\section{A. Amaç Ve Yöntem}

Bu çalışmada 2010-2012 yılları arasında BIST Kimya, Petrol, Plastik Endeksinde yer alan işletmelerin GRI (Global Reporting Initiative - Küresel Raporlama Girişimi) tarafından belirlenmiş sosyal sorumluluk kriterlerine göre raporlama düzeyinin belirlenmesi ve elde edilen sonuçların finansal performans ölçütleri ile olan ilişkisinin analiz edilmesi amaçlanmaktadır. İşletmelere ait veriler faaliyet raporlarından elde edilmiştir. Bu çalışmada işletmelerin sosyal sorumluluk düzeyini ölçebilmek için GRI kriterleri esas alınmıştır. Küresel Raporlama Girişimi (GRI), sürdürülebilirlik raporlamasının tüm kurumlar tarafından yapılmasını teşvik eden bir kuruluştur ve dünyada yaygın bir şekilde 
A. B. Başar / Kurumsal Sosyal Sorumluluk Raporlaması ve Finansal Performans Arasındaki Ilişski: Borsa İstanbul'da İşlem Gören Kimya-Petrol-Plastik Sektörü Şirketleri Üzerine Bir Araştırma

kullanılan kapsamlı bir sürdürülebilirlik raporlaması çerçevesi geliştirmektedir. $\mathrm{Bu}$ raporlama çerçevesi, Raporlama İlkeleri de dahil olmak üzere, kurumların ekonomik, çevresel ve sosyal performanslarını ölçmeleri ve raporlamaları için kullanmaları gereken Prensip ve Göstergeleri belirler. GRI, herkesin kullanımına açık olan bu İlkelerin kullanımının yaygınlaşması ve sürekli iyileşmesine büyük önem vermektedir. (https://www.globalreporting.org/languages/Turkish/Pages/default.aspx) GRI ilkeleri ekonomik, çevresel ve sosyal boyutta toplanmaktadır. Ayrıca bu boyutlar daha sonra

- Ekonomik

- Çevre

- İş gücü uygulamaları

- İnsan haklar1

- Toplum

- Ürün sorumluluğu

olarak sıralanabilecek göstergelerden oluşmaktadır. $\mathrm{Bu}$ altı gösterge her işletmenin sosyal sorumluluk düzeylerinin ölçülmesinde esas olarak alınmıştır.

Ekonomik:Ekonomik göstergeler sürdürülebilirliğin ekonomik boyutu bir kurumun kendi paydaşlarının ekonomik koşulları ile yöresel, ulusal ve küresel seviyelerde ekonomik sistemler üzerinde yarattı̆gı etkiler ile ilgilidir. Ekonomik Göstergeler ekonomik performans, işletmenin piyasaki konumu, dolaylı ekonomik etkiler başlıkları altında incelenmektedir. Bu kapsamda yapılacak açıklamalar aşağıdaki kapsamda toplanmaktadır.

- Gelirler, işletme maliyetleri, çalışan ücretleri, bağışlar ve diğer toplumsal yatırımlar, birikmiş kârlar ve sermaye sağlayıcıları ile devletlere yapılan ödemeler de dâhil, üretilen ve dağıtılan doğrudan ekonomik değer.

- İklim değişikliğinin kurumun mali sonuçlarına etkisi ve faaliyetlerinde yarattığı diğer riskler ve firsatlar.

- Kurumun tanımlanmış fayda planı yükümlülüklerinin kapsamı.

- Devletten alınan önemli mali destek.

- Önemli operasyon yerlerinde yerel tedarikçilere yapılan ödemelerle ilgili politikalar, uygulamalar ve harcama oranları.

- Önemli operasyon yerlerinde yerel işe alma usulleri ve yerel halktan işe alınmış üst yöneticilerin oranı.

- Ticari, ayni veya hayır amaçlı girişimlerle, öncelikli olarak kamu yararına yapılan altyapı yatırımlarının ve sağlanan hizmetlerin geliştirilmesi ve etkisi

Çevre: Sürdürülebilirliğin çevresel boyutu, bir kurumun ekosistemler, toprak, hava ve su da dâhil olmak üzere, canlı ve cansız doğal sistemler üzerinde yarattığı etkileri ile ilgilidir. Çevresel Göstergeler girdilerle (ör. malzeme, enerji, su) ve çıktılarla (ör. emisyon, katı ve sıv1 atıklar) ilgili performansı kapsar. 
Ayrıca, biyoçeşitlilik ve çevresel uyumun yanı sıra, çevresel harcama ve kurumun sunduğu ürün ve hizmetlerin yarattı̆̆ etkiler gibi diğer ilgili bilgileri de kapsar. Söz konusu göstergeler aşağıdaki unsurlardan oluşmaktadır.

- Malzemeler

- Enerji

- $\mathrm{Su}$

- Biyoçeşitlilik

- Emisyonlar, Sıvı ve Katı Atıklar

- Ürün ve Hizmetler

- Uyum

- Ulaştırma

- Genel

İşü̈cü Uygulamaları ve İnsana Yakışır İş: İşgücü uygulamaları ve insana yakışır iş göstergeleri kapsamında ILO Çokuluslu İşletmeler ve Sosyal Politika ile ilgili İlkeleri Üçlü Deklarasyonu ve Ekonomik İşbirliği ve Kalkınma Örgütü (OECD) Çokuluslu İşletmeler Genel İlkeleri öncelikli referans noktaları olarak alınmaktadır. Söz konusu kriterler aşağıdaki unsurlardan oluşmaktadır.

- İstihdam

- İşücü/Yönetim İlişkileri

- İş Sağllğı ve Güvenliği

- Eğitim ve Öğretim

- Çeşitlilik ve Fırsat Eşitliği

Insan Hakları: Sürdürülebilirliğe ilişkin insan hakları göstergeleri kurumların insan haklarının yatıım ve tedarikçi ya da yüklenici seçimi uygulamalarında ne ölçüde göz önünde tutuldukları konusunda rapor hazırlamalarını gerektirir. Buna ek olarak, göstergeler çalışanların ve güvenlik personelinin insan hakları ve aynı zamanda ayrımcılık yapmama, örgütlenme özgürlüğü, çocuk işçiliği, yerli hakları ve zorla ve zorunlu tutarak çalıştırma konularında da eğitilmesini kapsar. Söz konusu kriterler aşağıdaki unsurlardan oluşmaktadır:

- Yatırım ve Satın Alma Uygulamaları

- Ayrimcilik Yapmama

• Örgütlenme Özgürlüğü ve Toplu Sözleşme

- Çocuk İşçiliğinin Kaldırılması

- Zorla ve Zorunlu Tutarak Çalıştırmanın Önlenmesi

- Şikayetler ve Mağduriyetlerle ilgili Uygulamalar

- Güvenlik Uygulamaları

- Yerli Hakları

Toplum: Toplum performans göstergeleri, kurumların içinde faaliyet gösterdikleri yerel toplumlar üzerindeki etkilerine odaklanır ve diğer sosyal kurumlarla girdikleri etkileşimlerden kaynaklanabilen risklerin nasıl yönetildiğini 
A. B. Başar / Kurumsal Sosyal Sorumluluk Raporlaması ve Finansal Performans Arasındaki İlişki: Borsa Ístanbul'da İşlem Gören Kimya-Petrol-Plastik Sektörü Şirketleri Üzerine Bir Araştırma

ve arabuluculuk yapıldığını açıklar. Özellikle de, rüşvet ve yolsuzluk, kamu politikası oluşturulmasına haksız müdahale ve tekelcilik uygulamaları ile ilgili riskler hakkındaki bilgilerden oluşur. Söz konusu göstergeler aşağıdaki unsurlardan oluşmaktadır:

- Yerel halk

- Yolsuzluk

- Kamu Politikası

- Rekabeti Kısıtlayan Davranış

- Uyum

Ürün Sorumluluğu: Ürün Sorumluluğuna yönelik göstergeler, rapor hazırlayan kurumun ürün ve hizmetlerinin müşteriler doğrudan etkileyen unsurlarını ele alır. Söz konusu kriterler aşağıdaki unsurlardan oluşmaktadır:

- Müşteri Sağlı̆̆1 ve Güvenliği

- Ürün ve Hizmet Etiketlemesi

- Pazarlama İletişimi

- Müşterinin Kişisel Gizliliği

- Uyum

\section{B. Bulgular ve Sonuç}

Seçilmiş olan altı adet sosyal sorumluluk kriteri açısından faaliyet raporları incelendiğinde söz konusu açıklamaların hem kurumsal yönetim ilkelerine uyum Beyanın da hem de faaliyet raporlarında da ayrıca açıklandığı görülmektedir. Sözkonusu dağılım aşağıda yer alan Tablo 2 'de gösterilmiştir. Buna göre 2010 yılında söz konusu kriterlerin hepsine faaliyet raporlarında yer veren şirket sayısı 5'tir. Bu rakam 2011 de 6 ve 2012 de 9 şirket olarak karşımıza çıkmaktadır.

Tablo 2: Yıllara Göre Açıklanan Sosyal Sorumluluk Göstergesi Sayısı

\begin{tabular}{|c|c|c|c|c|c|c|}
\hline & \multicolumn{2}{|c|}{2010} & \multicolumn{2}{|c|}{2011} & \multicolumn{2}{|c|}{2012} \\
\hline $\begin{array}{l}\text { Açıklanan } \\
\text { Kriter Say1S1 }\end{array}$ & Siklık & Yüzde & Siklık & Yüzde & Siklık & Yüzde \\
\hline 1,00 & 1 & 5,0 & 1 & 5,0 & - & - \\
\hline 3,00 & 2 & 10,0 & 5 & 25,0 & 4 & 20,0 \\
\hline 4,00 & 5 & 25,0 & 3 & 15,0 & 3 & 15,0 \\
\hline 5,00 & 7 & 35,0 & 5 & 25,0 & 4 & 20,0 \\
\hline 6,00 & 5 & 25,0 & 6 & 30,0 & 9 & 45,0 \\
\hline Total & 20 & 100,0 & 20 & 100,0 & 20 & 100,0 \\
\hline
\end{tabular}


Söz konusu açıklamaların gösterge başlıklarına göre dağılımı ise aşağıda yer alan Tablo 3'de gösterilmektedir. Buna göre 2010 yılında en fazla işgücü ve toplum kriterine, 2011, ve 2012 yıllarında da en fazla yine işgücü kriterine göre raporlama yapıldığı, görülmektedir.

Tablo 3: Sosyal sorumluluk açıklamalarının kriterlere göre dağılımı

\begin{tabular}{|l|l|l|l|l|l|l|}
\hline & Ekonomik & Cevre & Isgucu & $\begin{array}{l}\text { Insan } \\
\text { Hakları }\end{array}$ & Toplum & Urun \\
\hline 2010 & 16,00 & 17,00 & 19,00 & 10,00 & 19,00 & 12,00 \\
2011 & 16,00 & 17,00 & 19,00 & 12,00 & 18,00 & 11,00 \\
2012 & 16,00 & 16,00 & 20,00 & 17,00 & 18,00 & 12,00 \\
\hline
\end{tabular}

Çalışmada sosyal sorumluluk raporlaması ile finansal performans arasındaki ilişkinin belirlenmesinde işletmenin finansal başarı ölçütü olarak hisse başına kazanç seçilmiştir. Esasında yatırımcılar açısından hisse başına kazanç hesaplaması önem taşımaktadır. Yani yatırımcılar açısından yapmış oldukları yatırıma göre işletmenin ne kadar karlı olduğunun göstergesi olarak kullanılmaktadır. Dolayısıyla işletme yöneticileri ve işletme yatırımcılarılar için hisse başına kazanç önemli bir göstergedir. Yatırımcılar bu verileri kullanarak karlı yatırım portföyünü oluşturmada temel olarak kullanabilirler. Diğer taraftan yöneticiler de sermaye yatırımları, faaliyet bütçeleri ve diğer kaynak dağılımı gibi önemli kararları bu verileri kullanarak alabilmektedirler. Bu nedenle finansal analistler bir işletmenin tüm performansını ölçmede kullanımı basit ve kolay olduğu için hisse başına kazanç üzerinde odaklanmışlardır. $\mathrm{Bu}$ açıdan bakıldığında net kar ve çıkarılmış olan hisseler arasındaki ilişkiyi açıkladığı vurgulanmaktadır. (Samy, Odemilin, Bampton, 2009)

İşletmelerin kurumsal sosyal sorumluluk faaliyetleri ile finansal performansı arasında ilişkinin yönünü ve gücünü belirleyebilmek için korelasyon analizi yapılmıştır . İyi finansal performansa sahip işletmelerin sosyal raporlamadan önceki yıllara ait finansal performansının bu raporlar üzerinde güçlü etkisi bulunduğu varsayılmaktadır.(Samy, Odemilin, Bampton, 2010) Bu durumda güçlü finansal yapıya sahip işletmelerin sosyal sorumluluk performansının da güçlü olacağı görüşünden hareket ederek öncelikle işletmenin önceki yıllara ait finansal performansı ile sosyal sorumluluk uygulamaları arasındaki ilişki incelenmiştir. Bu nedenle hisse başına kar ortalamaları ile 2012 sosyal sorumluluk verileri karşılaştırılmıştır. Söz konusu korelasyon Tablo 4'de gösterilmektedir.

Tablo 4'den de görülebileceği gibi geçmiş finansal performans ile sosyal sorumluluk açıklamaları arasında ters yönlü ve zayıf denebilecek güçte bir ilişki bulunmaktadır. Yani geçmiş yıllara ilişkin finansal performans ile sosyal sorumluluk raporlaması ters yönde hareket etmektedir. 
A. B. Başar / Kurumsal Sosyal Sorumluluk Raporlaması ve Finansal Performans Arasındaki Ilişski: Borsa İstanbul'da İslem Gören Kimya-Petrol-Plastik Sektörü Şirketleri Üzerine Bir Araștırma

Tablo 4: Sosyal Sorumluluk Açıklamaları ile Önceki Yıllara Ait Hisse Başına Kar Ortalamaları İlişkisi

\begin{tabular}{|ll|r|r|}
\hline & & Aciklama2012 & Ortalamahbk \\
\hline Aciklama2012 & Pearson Correlation & 1 &,- 214 \\
& Sig. (2-tailed) & &, 364 \\
& $\mathrm{~N}$ & 20 & 20 \\
Ortalamahbk & Pearson Correlation &,- 214 & 1 \\
& Sig. (2-tailed) &, 364 & \\
& $\mathrm{~N}$ & 20 & 20 \\
\hline
\end{tabular}

Diğer taraftan, kurumsal sosyal sorumluluk ile ilgili uygulamaların savunucuları bu yolla işletmelerin toplumda sosyal sorumluluk sahibi varlık olarak olumlu algı yaratması aracılığıyla karlarını arttırabileceği yönünde görüş öne sürülmektedirler. $\mathrm{Bu}$ durumda yapılmış olan sosyal sorumluluk açıklamalarının ertesi yılların finansal performansı arasındaki ilişkiyi ortaya koymak amaciyla da 2010 yılı sosyal sorumluluk verileri ile ertesi y1llara ait hisse başı ortalamaları arasındaki ilişki de araştırılmıştır. Söz konusu ilişki Tablo 5'de gösterilmektedir.

Tablo 5: Sosyal Sorumluluk Açıklamaları İle Ertesi Yıllara İlişkin Hisse Başına Kar Ortalamaları İlişkisi

\begin{tabular}{|ll|r|r|}
\hline & & Aciklama2010 & Ortalamahbk \\
\hline Aciklama2010 & Pearson Correlation & 1 &,- 257 \\
& Sig. (2-tailed) & &, 273 \\
& $\mathrm{~N}$ & 20 & 20 \\
Ortalamahbk & Pearson Correlation &,- 257 & 1 \\
& Sig. (2-tailed) &, 273 & \\
& $\mathrm{~N}$ & 20 & 20 \\
\hline
\end{tabular}

Yukarıdaki tablodan da görülebileceği gibi raporlanmış olan sosyal sorumluluk faaliyetleri ile ortalama hisse başı kazanç tutarları arasında da ters yönlü ilişki bulunmakla birlikte bu ilişkinin gücü de zayıf denebilecek seviyededir.

Sonuç olarak BIS petrol kimya ve plastik sektöründe faaliyet gösteren işletmeler açısından işletmelerin sosyal sorumluluk açıklamaları ile hisse başına kazanç tutarları arasında ters yönlü bir ilişki bulunduğu söylenebilir. Bu ilişki hem bu yönde yapılan açıklamaların onu takip eden yıllara ilişkin hisse başına kar ortalaması açısından hem de önceki yıllar hisse başına kazanç ortalaması ile takip eden yıla ilişkin sosyal sorumluluk açıklaması açısından da geçerlidir. Buna göre sosyal sorumluluk faaliyetlerinden dolayı işletmeler maliyetlere katlanmaktadırlar bu da diğerlerine göre ekonomik açıdan dezavantajlı konuma getirmektedir. $\mathrm{Bu}$ nedenle de ele alınan sektörler açısından finansal performans ile sosyal sorumluluk faaliyetleri arasında zayıf güçte de olsa ters yönde ilişki bulunduğu söylenebilir. 


\section{Kaynakça}

Aktan, C. , Börü, D. (2007) "Kurumsal Sosyal Sorumluluk" Ed. Coşkun Can Can Aktan Kurumsal Sosyal Sorumluluk: İşletmeler ve Sorumluluk, İGİAD Yayınları, İstanbul.

Allouche, J Laroche, P. (2005) "A Meta-Analytical Investigation Of The Relationship Between Corporate Social And Financial Performance "Revue de Gestion des Ressources Humaines pp. 18-41.

Andersen, M. Olsen, L. "Corporate Social and Financial Performance: A Cononical Correlation Analysis" Academy of Accounting and Financial Studies Jornal, V.15. N.2. pp. 17-37

Aras ve G., Aybars, A., Kutlu, O. , (2010) Managing Corporate Performance: Investigating the Relationship Between Corporate Social Responsibility and Financial Performancein Emerging Markets" International Journal of Productivity and Performance Management, Vol. 59, No.3. pp. 229-254

Arsoy, A. Arabacı, Ö., Çiftçioğlu, A. (2012)" Corporate Social Responsibility and Financial Performance Relationship: The Case Of Turkey" Muhasebe ve Finansman Dergisi, Ocak. Pp. 159-176.

Aupperle, K., Carroll, A. and Hartfield, J. (1985), "An empirical examination of the relationship between corporate social responsibility and profitability", Academy of Management Journal, Vol. 28 No. 2, pp. 446-63.

Balabanis, G., H. C. Philips and J. Lyall (1998) "Corporate Social Responsibility and Economic Performance inthe Top British Companies: Are They Linked?", European Business Review V. 98, N. 1, pp. 25-42.

Başar, Başar (2006) "Sosyal Sorumluluk Raporlaması ve Türkiye'deki Durumu” Anadolu Üniversitesi Sosyal Bilimler Dergisi, Vol. 6. N. 2, pp. 213-230.

Beurden, p. Gössling, T. (2008) The Worth of Values: Aliterature Review on the Relation Between Corporate Social and Financial Performance" Journal of Business Ethics, V. 82, pp. 407424.

Chand, M. (2006) "The Relationship Between Corporate Social Performance and Corporate Financial Performance: Industry Type as a Boundry Type", The Business Review, Vol5. N. 1. Pp. 240- 245.

Cohran ve Wood, Corporate Social responsibility and Financial Performance, Academy of Management Journal, 1984, Vol 27, No.1

D'Arcimoles, C.H. and Trebucq, S. (2002), "The corporate social performancefinancialperformance link: evidence from France", paper prepared and accepted for the 2002 AFFI International Conference, Paris.

Graves, S. and Waddock, S.A. (1994), "Institutional owners and corporate social performance", Academy of Management Journal, Vol. 18, pp. 303-17.

Lech. A.(2012) “Corporate Social responsibility and Financial Performance: Theoretical and Emprical Aspects"

Martin, S. , Odemilin G. Bampton, R. ((2010. (2010): 203-217.”Corporate Social Responsibility: A Strategy For Sustainable Business Success. An Analysis Of 20 Selected British Companies " Corporate Governance, Vol 10, No.2. 10.2

McGuire, J. B., A. Sundgren and T. Schneeweis: (1988), "Corporate Social Responsibility and Firm Financial"Sustainable Development and Corporate Performance"Performance, Academy of Management Journal , Vol. 31 N. 4, pp. 854-872.

Moneva, j, Rivera, J. M.. Muño-Torres, M. (2007) "The Corporate Stakeholder Commitment And Social And Financial Performance" Industrial Management \& Data Systems, Vol. 107. No. 1. pp. 84-102

Moore, G. (2001)“Corporate Social and Financial Performance: An Investigation in the U.K. Supermarket Industry" Journal of Business Ethics, 34. pp. 299-315.

Oeyono, J. Samy, M., Bampton, R. (2011), “An Examination of Corporate Social Responsibility and Financial Performance: A Study of top 50 Indonesian Listed Companies"Jornal of Global Responsibility, Vol. 2, No: 1, 100-112 pp. s. 101 
A. B. Başar / Kurumsal Sosyal Sorumluluk Raporlaması ve Finansal Performans Arasındaki İlişki: Borsa İstanbul'da İşlem Gören Kimya-Petrol-Plastik Sektörü Şirketleri Üzerine Bir Araştırma

Pava, M. L. and J. Krausz, (1996), 'The Association BetweenCorporate Social-Responsibility and Financial Performance: The Paradox of Social Cost', Journal of Business Ethics V. 15 N. 3, pp. 321-357.

Preston, L., O'Bannon, D. ( 1997) “The corporate social-financial performance relationship" Business and Society;; V.36, N. 4; pp. 419- 429

Velde. E. Vermeir, W., Corten. (2005) "Corporate Soacila Responsibility and Financial Performance" Corporate Governance, Vol. 5. No. 3. Pp. 129-138.

(https://www.globalreporting.org/languages/Turkish/Pages/default.aspx) 